\title{
Commentary
}

\section{Vagrancy Laws and International Labor Standards: African Reform of Criminal Laws}

\author{
By Anneke Meerkotter, Executive Director, Southern Africa Litigation Centre, \\ Johannesburg, South Africa
}

\section{Introduction}

In December 2020, the African Court on Human and Peoples' Rights (African Court) issued an Advisory Opinion on the extent to which laws that criminalize individuals' status as poor, homeless, or unemployed violate their human rights. ${ }^{1}$ The African Court declared these offenses contrary to the rights enshrined in the African Charter on Human and Peoples' Rights, the African Charter on the Rights and Welfare of the Child, and the Protocol to the African Charter on Human and Peoples' Rights on the Rights of Women in Africa. ${ }^{2}$

The African Court's Advisory Opinion has at least three crucial labor law implications: first, on a practical level, it endeavors to bring outdated laws in line with international labor standards and long-outstanding government

1 African Court on Human and Peoples' Rights, Advisory Opinion following Request for an Advisory Opinion by the Pan African Lawyers Union (PALU) on the compatibility of vagrancy laws with the African Charter on Human and Peoples' Rights and other human rights instruments applicable in Africa, No. 001/2018, 4 December 2020.

2 G.A. Res. 2200A (XXI), Article 10 (March 23, 1976); Organization of African Unity, African (Banjul) Charter on Human and Peoples' Rights, Article 5, OAU Doc. CAB/LEG/67/3 rev. 5, 21 I.L.M. 58 (1982), entered into force 21 October 1986 (African Charter); African Charter on the Rights and Welfare of the Child, Organisation of African Unity Doc. CAB/LEG/24.9/49 (1990) entered into force 29 November 1999 (Children's Charter); Protocol to the African Charter on Human and Peoples' Rights on the Rights of Women in Africa, adopted 11 July 2003 (Maputo Protocol). 
obligations. Second, on a jurisprudential level, it broadens the understanding of prohibited grounds of discrimination. Finally, on a principled level, it requires each state to consider how its criminal laws inhibit its commitments to broaden work opportunities. States are now required to review their laws to ensure that they do not discriminate or dehumanize persons. ${ }^{3}$ This requires a review of the laws themselves and how they are enforced. The International Labour Organization (ILO) has a vital role to play in monitoring and supporting the law reform process.

\section{Aligning National Laws with International Labor Standards}

The Court considered a range of offenses across Africa that criminalize a person for having no fixed home, employment, or means of subsistence, ${ }^{4}$ for being a suspected person or reputed thief who has no visible means of subsistence and cannot give a good account of him or herself; 5 or for being idle, lacking visible means of subsistence, and unable to give a good account of him or herself. 6 These offenses are loosely described as vagrancy laws.

Colonial powers did not hesitate to use slavery and, after it was abolished, ${ }^{7}$ forced labor to provide for the needs of settler communities. ${ }^{8}$ Colonial governments also used indirect measures such as vagrancy laws and taxes to force people to work for private companies, European agricultural estates, mines, or government projects. ${ }^{9}$

In 1930, the ILO raised specific concerns about how colonial governments were using indirect measures to pressure the population to seek wage-earning

3 African Court on Human and Peoples' Rights, Advisory Opinion No. 0o1/2018, para. 155.

4 Eswatini, Namibia, and Zimbabwe have retained specific Vagrancy Acts. Some countries have specific Penal Code provisions criminalizing being a vagrant: Algeria, Burundi, Burkina Faso, Cameroun, Chad, Comoros, Republic of Congo, Côte d'Ivoire, Gabon, Guinea, Madagascar, Mauritania, Mali, Morocco, Niger, Sahrawi Arab Democratic Republic, Senegal, and Togo.

5 The Penal Codes of Botswana, the Gambia, Malawi, Nigeria, Seychelles, Tanzania, Uganda, and Zambia have specific provisions relating to being an idle and disorderly person and being a rogue and vagabond.

6 The laws of Central African Republic, Ethiopia, Eritrea, Mauritius, Sierra Leone, Sudan, and South Sudan.

7 For example, the Convention to Suppress the Slave Trade and Slavery, 25 September 1926, urged the progressive abolition of slavery and forced and compulsory labor.

8 Marcel de Coppet, "Manpower Problems and Prospects in Madagascar," International Labour Review 59, no. 3 (1949): 249-70.

9 Sanderson Beck, "East Africa 1700-1950," in Mideast \& Africa 1700-1950: Ethics of Civilisation, vol. 16 (2010). 
employment, including taxation, land restrictions, pass laws and "extending abusively the generally accepted meaning of vagrancy."10 It did not, however, go further than saying that removing these measures was "desirable."

After World War II, the Houphouët-Boigny Law of 1946 prohibited forced and compulsory labor in all French overseas territories. ${ }^{11}$ Britain's Colonial Office made similar demands on its colonies to ensure compliance with the new ILO treaties. ${ }^{12}$ These efforts did not deter the use of indirect measures to extract labor from colonial subjects.

Although the ILO passed other conventions to better regulate the work environment, ${ }^{13}$ only in 1957, through the Abolition of Forced Labour Convention, were states required "to suppress and not make use of any form of forced or compulsory labour."14 As labor law standards improved, vagrancy laws were retained and enforced for purposes other than extracting labor. Vagrancy offenses have since become a catch-all offense to address a range of "undesirable" behaviors while sidestepping criminal law and procedure requirements. These offenses also continue to be used to harass informal economy workers. The use of vagrancy laws has come to the ILO's attention, mostly to the extent that persons prosecuted as vagrants are forced into work or community service, but the impact of vagrancy laws on the ability of people to access livelihoods remains largely unrecognized..$^{15}$

The Court's call on states to review all their criminal laws correlates with the obligation imposed on all ILO Member States to remove laws that facilitate forced labor. The African Court's Advisory Opinion now raises the urgency with which these offenses must be reformed to ensure that they meet obligations under international law.

10 Forced Labour (Indirect Compulsion) Recommendation, 1930 (No. 35), Geneva, ILC 14th Session (28 June 1930), Article II.

$11 \quad$ De Coppet, "Manpower Problems."

12 Alexander Burton and Paul Ocobock, "The 'Travelling Native': Vagrancy and Colonial Control in British East Africa," in Cast Out: Vagrancy and Homelessness in Global and Historical Perspective, ed. A. L. Beier and Paul Ocobock (Athens: Ohio University Press, 2008).

13 For example, the Protection of Wages Convention, 1949, which provides for the regular payment of wages.

14 Abolition of Forced Labour Convention, 1957, Article 1.

15 For example, Direct Request (CEACR) - adopted 2017, published 107th ILC session (2018), Forced Labour Convention, 1930 (No. 29) - Rwanda (Ratification: 2001), para 2 (punishment of vagrancy). 


\section{Broadening the Prohibited Grounds of Discrimination}

The Advisory Opinion concluded that vagrancy laws violate a range of fundamental rights, including those against discrimination and to equal protection under the law.

Article 2 of the African Charter provides that all persons are entitled to the rights and freedoms in the Charter, "without distinction of any kind such as race, ethnic group, colour, sex, language, religion, political or any other opinion, national and social origin, fortune, birth or any other status." Article 3 of the Charter entitles every individual to equality before the law and equal protection of the law. The African Court and the African Commission's position is that Article 2 is necessary to eradicate all forms of discrimination, and Article 3 focuses on "fair and just treatment of individuals within a legal system."16

In its Advisory Opinion, the Court emphasized that the phrase "any other status" in Article 2 of the Charter "encompasses those cases of discrimination, which could not have been foreseen during the adoption of the Charter."17 This approach is consistent with emerging jurisprudence in Africa, which has interpreted the prohibited grounds of discrimination in national constitutions to be nonexhaustive. ${ }^{18}$

The Advisory Opinion found that vagrancy laws fall within the prohibited ground of discrimination of "other status." In so doing, the Court made several pronouncements: first, that vagrancy laws make a distinction between persons classified as vagrants and the rest of the population, based solely on their economic status; ${ }^{19}$ second, that laws with discriminatory effect toward marginalized groups are also in violation of the right to equal protection; ${ }^{20}$ and, third, that arrests under these laws, based solely on underprivileged status, are also contrary to Articles 2 and 3 of the Charter. ${ }^{21}$

16 African Court on Human and Peoples' Rights, Advisory Opinion No. oo1/2018, para. 68; Purohit and Moore v. The Gambia, Communication No. 241/2001, para. 49, Zimbabwe Lawyers for Human Rights and Institute for Human Rights and Development in Africa, Comm. 294/04 (3 April 2009), para. 99.

17 African Court on Human and Peoples' Rights, Advisory Opinion No. oo1/2018, para. 66.

18 Industrial Court of Malawi, Banda v. Lekha (277 of 2004) [2005] MWIRC 44 (1 June 2005); High Court of Botswana [2019], LM v. Attorney General, MAHB G-ooo591-16; Court of Appeal of Botswana, Attorney General of Botswana v. Rammoge and 19 Others, Civil Appeal No. CACG B-128-14 [2016], para. 58; Industrial Court of Eswatini, Satellite Investments v. Dlamini and Others [2011] szICA 5, paras. 25-26; Industrial Court of Botswana, Diau v. Botswana Building Society, IC Case No. 50 of 2003.

19 African Court on Human and Peoples' Rights, Advisory Opinion No. oo1/2018, para. 72.

$20 \quad$ Ibid., para. 73 .

21 Ibid., para. 74. 
The Court applied an intersectional approach, looking at the impact of the vagrancy laws on women, children, and marginalized groups, and the extent to which the derogatory words and practices associated with these offenses violated the right to dignity.

The Advisory Opinion cuts through some of the concerns often raised in relation to poverty as a prohibited ground of discrimination. For example, Canadian jurisprudence seems to interpret the prohibited grounds of discrimination in the Canadian Charter of Rights and Freedoms as applying only to enumerated or analogous grounds. ${ }^{22}$ Canadian courts have taken the position that discrimination on the grounds of poverty is not analogous and would only be considered to the extent of evidence that discrimination based on poverty results in discrimination on an enumerated ground. ${ }^{23}$

South African courts have been willing to take poverty into consideration as part of the intersectional analysis but do not stray far from the enumerated and analogous grounds of discrimination. For example, in a South African High Court case relating to persons who had begged on private property, the applicant sought a permanent interdict restraining the respondents from accessing its property (a private commercial complex accessible to the public). ${ }^{24}$ The Court held that property rights must give way to the rights to life and dignity, holding that in the context of South Africa's history, "the practice of excluding people from parts of a city, albeit for limited periods, may appear repugnant." In November 2020, the South African Constitutional Court considered the extent to which the failure to include domestic workers in social security protections was discriminatory. ${ }^{25}$ The Court noted that intersectional discrimination's cumulative effect exacerbates domestic workers' already compromised position in society and marginalizes them further. The Court noted that where a law or policy fails to take cognizance of the most vulnerable and those in most desperate need, it is unreasonable. Similarly, the African Court explained,

vagrancy laws effectively punish the poor and underprivileged, including but not limited to the homeless, the disabled, the gender-nonconforming, sex workers, hawkers, street vendors, and individuals who otherwise

\footnotetext{
22 Witherv. Canada (Attorney General) [2011] 1 S.C.R. 396, paras. 29-34.

$23 \quad R v$. Sutherland [2018] 398 CR R (2d) 227, para. 16.

24 Victoria \& Alfred Waterfront (Pty) Ltd and Anotherv. Police Commissioner of the Western Cape and Others [2004] 5 BCLR 538 (C).

25 Mahlangu and Anotherv. Minister of Labour and Others [2021] 2 BLLR 123 (CC), 19 November 2020 .
} 
use public spaces to earn a living. Notably, however, individuals under such difficult circumstances are already challenged in enjoying their other rights, including more specifically their socio-economic rights. ${ }^{26}$

This approach was also adopted by the African Commission on Human and Peoples' Rights in its Principles on the Decriminalisation of Petty Offences, which define "vulnerable persons" as "persons who are marginalised in society and the criminal justice system because of their status, or an intersection of one or more statuses." 27

The Advisory Opinion adds weight to equality jurisprudence that incorporates intersections of vulnerability in its analysis and brings to the fore how the legal framework historically enforces such forms of vulnerability.

The Court's decision is important for recognizing poverty as a prohibited ground of discrimination. In so ruling, the Court moves away from the argument that poverty cannot be a prohibited ground of discrimination because it is not immutable in the way that race and sex, for example, are. ${ }^{28}$ Vagrancy laws are perhaps the most apparent manifestation of discrimination based on poverty because they explicitly criminalize the status of having no means of subsistence. How vagrancy laws are applied today is a further manifestation of discrimination based on poverty: police officers, prosecutors, and magistrates, consciously or unconsciously, treat persons who are poor or appear poor with less respect and are more likely to violate their procedural rights than those of persons who are not poor.

\section{Supporting the Right to Access Work Opportunities}

Vagrancy laws do not correlate with the fact that all persons, regardless of socioeconomic status, ought to be entitled to inhabit and frequent cities and towns, including to access opportunities for jobs. The African Court's opinion acknowledged that these laws punish persons earning a living in public spaces and people who access such spaces to seek work opportunities. The Advisory Opinion accordingly held that the enforcement of vagrancy laws is contrary to the obligation to protect the rights of women, children, and persons with disabilities. ${ }^{29}$

\footnotetext{
26 African Court on Human and Peoples' Rights, Advisory Opinion No. 001/2018, para. 70.

27 African Court on Human and People's Rights, Principles on the Decriminalisation of Petty Offences (2017).

28 Peterman, D. E. 2018. "Socioeconomic Status Discrimination" Virginia Law Review 104: 1283-1359.

29 African Court on Human and People's Rights, Advisory Opinion No. oo1/2018, para. 139.
} 
The enforcement of vagrancy laws thus arguably infringes on obligations under ILO conventions. For example, Article 1 of ILO Convention No. 111 recognizes "equality of opportunity," which ought to extend to the ability of persons to access work opportunities. ${ }^{30}$ Also, Article 2 of ILO Convention No. 190 states that the convention includes protection for working persons regardless of their contractual status, job seekers, and job applicants, and applies to both the formal and informal economy. Article 8 requires states to "take appropriate measures to prevent violence and harassment in the world of work," including by recognizing the role public authorities play in the case of informal economy workers. ${ }^{31}$ Individuals who traverse urban areas in search of work opportunities ought to be protected from vagrancy laws that seek to eject them from those spaces. This can only be done if states invest in ensuring that law enforcement agencies operate in a manner that respects all persons' rights regardless of their actual or perceived status.

30 The Discrimination (Employment and Occupation) Convention (No. 111), adopted 25 June $195^{8}$, entered into force 15 June 1960 .

31 The Violence and Harassment Convention (No. 190), adopted 21 June 2019, entered into force 25 June 2021. 